\title{
Analyzing the Link between Dollars and Decisions: A Multi- State Study of Campaign Contributions and Judicial Decision Making
}

\author{
Ryan J. Rebe \\ William Paterson University
}

This article examines the connection between attorney contributions and judicial decisions in states with contested elections. The results show that contributions are a significant predictor of appellant success in state supreme courts when judges receive contributions from the attorneys for the appellant. However, this relationship is contingent on the competitiveness of the judicial seat. The analysis shows that judges who received a low percentage of the vote in the previous election are more likely to vote with contributors than judges who received a high percentage. This evidence suggests that judges behave differently when they are electorally vulnerable. The results also support the proposition that elected judges are more likely to vote with donors in states with nonpartisan ballots, when controlling for other factors. While the contribution amounts are much higher in partisan states, the judges in the nonpartisan states are more closely aligned with their contributors when it comes to decision making.

Are state judges for sale? This is the question at the center of an ongoing debate about the risk that campaign fundraising poses to the impartial administration of justice. In some states, judicial elections have become "slick, professionalized affairs featuring high-dollar campaigns, expensive television advertising, and increasing influence from parties and interest groups" (Arbour and McKenzie 2010, 150). While there is some variation among the states, the average cost of campaigning is increasing exponentially nationwide (Skaggs et al. 2011). Since 2000 , twenty out of the twenty-two states with competitive elections have shattered their previous fundraising records (Skaggs et al. 2011). In some states, the cost of running a judicial race has become as expensive as that of either Congressional races or even presidential campaigns (Geyh 2003). Consequently, judicial candidates are spending more for campaign ads, polls, and even consultants (Geyh 2003).

The question is how this infusion of money affects judicial behavior. Are elected judges biased towards their contributors? On the one hand, there is evidence that competitive elections may compromise judicial independence (Cann 2007). Several studies link campaign contributions to case outcomes (McCall 2003; Shepherd 2009; Waltenburg and Lopeman 2000; Ware 1999). But, this relationship may only exist under certain circumstances (Cann et al. 2012), and there remains a question of causality. Establishing causality between contributions and votes is difficult since contributors may simply give to candidates who are already inclined to vote in their direction (Bonneau 2012).

Moreover, there is clearly a need for more research from a larger sample of states. "It is difficult to get a lot of analytical leverage out of a small number of states" when the results are contradictory from one state to the next (Bonneau 2012,6). This is especially true considering that the rise in campaign contributions is not uniform across all states. ${ }^{1}$ While some states have loosened their restrictions, others have sought to curb spending. For instance, in 2004, two candidates for the $5^{\text {th }}$ Judicial District seat on the Illinois Supreme Court set a record for the most 
expensive judicial contest in history (the contest raised a combined $\$ 9.3$ million). Conversely, in 2002, the North Carolina General Assembly passed the Judicial Campaign Reform Act, and became only the second state (after Wisconsin) to institute publicly financed campaigns. Although recently repealed, the purpose of this electoral reform was to stem the tide of campaign contributions.

This study contributes to research on this topic in three ways. First, by testing whether electoral vulnerability affects judicial decision-making when judges receive campaign contributions, second, by including a large sample of cases from a diverse set of states, and third, by testing the significance of ballot type. The findings indicate that the strength of the relationship between contributions and votes is contingent on the competitiveness of the judicial seat. That is, judges who run in closely contested races are more likely to vote with contributors than judges who win a large percentage of the vote or run uncontested. This finding suggests that electoral pressure forces judges in competitive seats to favor contributors in order to win reelection and secure their place on the bench.

\section{Previous Literature}

The idea that judges are subject to extralegal influences is not a new one, but the public and legal community have always maintained a certain level of denial about the political pressures exerted on elected judges (Geyh 2016). However, this illusion is becoming harder to maintain in light of a growing body of research indicating the judiciary is undergoing a political transformation (Geyh 2016). In recent decades, the empirical evidence that elected judges are responsive to extralegal influences has grown dramatically (Brace and Hall 1997; Cann and Wilhelm 2011; Hall 1992; Hall 1995; Langer 2002).

One of the main areas of concern is the influx of money into judicial elections, which is why there has been increased attention by judicial scholars to the effects of campaign contributions on judicial decision making (Bonneau 2005; Hall and Bonneau 2006). Advocates of an independent judiciary free from electoral pressures cite the growing number of studies showing a relationship between contributions and case outcomes. In a study of arbitration cases in Alabama, Ware (1999) finds that judges funded by plaintiffs' lawyers tend to oppose arbitration, while judges funded by business interests are more likely to support arbitration. Waltenburg and Lopeman (2000) reach a similar conclusion in their study of tort cases in Alabama, Kentucky, and Ohio. They find that the effect of contributions depends on the timing of the decision. Following an election, judges show no signs of being influenced by contributors, but as elections approach, their decisions more closely align with their contributors' preferences.

On the other hand, defenders of judicial elections cite a lack of empirical evidence that contributions directly lead to favorable treatment from elected judges, since establishing causality between money and votes is methodologically difficult (Bonneau 2012). Although many scholars believe businesses and lawyers fund campaigns in order to influence decisions, it is difficult to find evidence that voting patterns are actually structured by these contributions (McCall 2003). It could be the case that contributors reward judges for past votes or to ensure that friendly judges remain on the bench (McCall 2003).

McCall's (2003) study is one of the few to provide evidence that decisions follow dollars and not the other way around. McCall (2003) studied the influence of campaign contributions on 
Texas Supreme Court justices from 1994-1997 in cases dealing with two business litigants. She focused specifically on votes where estimates of judicial ideology did not explain the direction of the vote. She called these "unexpected votes." These cases typically involved large corporations being sued for breach of contract or unfair business practices (McCall 2003). Since all of the justices on the Texas Supreme Court are conservative, they should favor defendants in these types of cases (McCall 2003). Thus, she looked at contributions from plaintiffs in the unusual cases where the judges ruled for the plaintiffs. By establishing a relationship between contributions and decisions for these types of cases, McCall (2003) concluded that her results establish a loose causal relationship between contributions and votes.

Unlike the previous studies which focused on a few states or case types, Shepherd (2009) collected data on virtually all state supreme court decisions from 1995-1998. She found that judges vote in ways intended to attract money from interest groups, and the relationship is strongest in states with partisan competitive elections. Shepherd's (2009) study is noteworthy for addressing causality by comparing retiring and non-retiring judges. Interestingly, she finds a difference in the behavior of retiring and non-retiring judges, which suggests that the decisions of non-retiring judges may be affected by the need to win reelection. ${ }^{2}$ If votes naturally followed interest group support based on ideological preferences the results would be the same for retiring judges (Shepherd 2009).

Building on Shepherd's (2009) work, it is important to look at the actual litigants that appear before the bench and not just groups that operate outside of the judicial process. When judges receive contributions from groups that appear before them in court, there are even greater concerns over impartiality. Along these lines, there are a few studies looking at attorney contributions, but the evidence is mixed. Cann's $(2002 ; 2007)$ studies of the Wisconsin (nonpartisan) and Georgia (nonpartisan) Supreme Courts yield contradictory results. He finds a relationship between attorney contributions and favorable decisions in Georgia, but not Wisconsin. In a similar study, Cann et al. (2012) looked at the relationship between contributions and decisions in Michigan (semi-partisan), Texas (partisan), and Nevada (nonpartisan). Their approach involved pairing judges with the same ideology. They found a strong relationship in Michigan, but not in Texas or Nevada. It is unclear what made the results in Michigan different than Texas and Nevada. ${ }^{3}$

Kang and Shepherd (2011) investigated contributions from business groups to judicial campaigns in every state supreme court case in all fifty states between 1995-1998. They found that "...every dollar of contributions from business groups is associated with increases in the probability that elected judges will decide for business litigants" (Kang and Shepherd 2011, 73). However, they contend this relationship only exists in the partisan sample, and therefore, campaign contributions do not influence the votes of judges elected under nonpartisan elections. In a follow-up study, Kang and Shepherd (2013) made a similar argument regarding the pivotal role political parties play in matching donors with judges. They assert that political parties “... have become the critical players in judicial campaign finance" (Kang and Shepherd 2013, 1258). 


\section{Competitive Elections}

Previous studies have overlooked the importance of competition for understanding the relationship between contributions and decisions. The fear of competition in the next election is the main reason why incumbents in elective states vote more closely with the public's demands (Gordon and Huber 2007). The biggest threat to a sitting judge is the prospect of a quality challenger, and quality challengers are more likely to run in states with competitive party politics (Hall and Bonneau 2006). "Competitive elections and the attendant risk of a viable challenger, force incumbent politicians to pay more heed to potential negative voter reactions to their behavior" (Gordon and Huber 2007, 133).

The probability that a judge will face a quality challenger in the next election is higher if the judge won by a small margin in the previous election because close elections are a sign of weakness to potential opponents (Bond, Covington, and Fleisher 1985). Prior studies indicate that the amount of voter support for the incumbent in the previous election is an important factor in determining whether a challenger will emerge (Bond, Covington, and Fleisher 1985; Hogan 2004; Pritchard 1992; Van Dunk 1997). Thus, we can expect judges who run in competitive races to more closely align their votes with contributors in order to avoid a challenger, while judges who win easily or run uncontested will be less responsive. It is the fear of competition that explains why elected judges reward contributors, and this fear is greater when judges win their seats in close elections. Accordingly, there should be a discernible difference between the voting patterns of judges who won a low percentage of the vote in the previous election and those who won a high percentage.

$\mathrm{H}_{1}$ : Judges who receive a low percentage of the vote in the previous election are more likely to vote with contributors than judges who receive a high percentage.

\section{Ballot Type}

Despite the flood of money into judicial campaigns in some states, popular support for a change from judicial elections to merit selection systems has actually declined over the last three decades (Andersen 2004). Since the vast majority of the public favors electing judges, judicial reformers are beginning to concede that judicial elections are here to stay (Geyh 2003). Consequently, instead of trying to end judicial elections altogether, reformers are trying to change the way elections are conducted (Bonneau and Cann 2011).

Some states have shifted to nonpartisan ballots and stricter contribution limits, and a few have even experimented with publicly funded campaigns. The idea is that nonpartisan ballots and strict contribution limits make judicial candidates less susceptible to political pressure from contributors because they alter the source and amount of campaign funds. In partisan elections, political parties and their supporters have a stake in the success of their candidates, and therefore, are willing to invest additional funds to help them (Bonneau 2005; Frederick and Streb 2011), making political parties the critical players in this process (Kang and Shepherd 2011:2013). On the other hand, nonpartisan candidates often must raise money on their personal qualifications alone (Bonneau 2005; Peters 2007), or spend more from their own coffers to get information to voters (Bonneau and Hall 2009; Rock and Baum 2010).

This line of reasoning explains why campaign spending is higher in partisan states (Shepherd 2009; Skaggs et al. 2011), but it ignores the way in which “...nonpartisan elections effectively break the policy linkage between citizens and their representatives..." (Wright and 
Schaffner 2002, 377). Nonpartisan candidates are less beholden to the electorate or political parties (Wright and Schaffner 2002), and therefore, are free to reward campaign contributors. By decreasing voter participation and the ability of voters to make informed choices, nonpartisan elections may actually encourage the worst aspects of judicial campaigns (Bonneau and Hall 2009). Thus, I expect judges in nonpartisan states to vote more often with their donors.

$\mathrm{H}_{2}$ : Judges in states with nonpartisan ballots are more likely to vote with contributors than judges in partisan states.

\section{Research Design}

\section{Data}

To test these hypotheses, I constructed an original data set of state supreme court cases from the 2011 and 2012 terms, and campaign contributions from attorneys to each judge in their previous election. I chose to focus on attorney contributions since they are the most common type of contribution to elected judges (McCall 2003). In order to obtain a representative sample from each state, I coded a random sample of twenty-five recent opinions by each court. Only published written opinions are included in the sample, but every case type was included except for attorney disciplinary hearings since they involve ethical rather than legal disputes. There are a total of 400 cases (25 per state) from sixteen state supreme courts.

There are nine states which maintain some form of partisan election. ${ }^{4}$ I included all of the partisan states in the sample, except for Texas which has two supreme courts - the Texas Supreme Court, which only hears civil cases, and the Texas Court of Criminal Appeals. For purposes of comparison, I selected the eight most populated nonpartisan states. Overall, the sample represents diverse regions, court sizes, term lengths, contribution limits and selection methods. 5 Table 1 provides descriptive statistics for each state. 
Table 1. Descriptive Statistics

\begin{tabular}{|c|c|c|c|c|c|}
\hline State & Selection Method & Limits $^{a}$ & Region & Term & Judges \\
\hline Georgia & Nonpartisan & $\$ 6,100$ & Southeast & 6 & 7 \\
\hline Kentucky & Nonpartisan & $\$ 1,000$ & Southeast & 8 & 7 \\
\hline Minnesota & Nonpartisan & No Limits $/ \$ 2,500^{\mathrm{b}}$ & Midwest & 6 & 7 \\
\hline Mississippi & Nonpartisan & $\$ 5,000$ & Southeast & 8 & 9 \\
\hline North Carolina & Nonpartisan & $\$ 1,000$ & Southeast & 8 & 7 \\
\hline Oregon & Nonpartisan & No Limits & Northwest & 6 & 7 \\
\hline Washington & Nonpartisan & No Limits/ $\$ 3,200^{c}$ & Northwest & 6 & 9 \\
\hline Wisconsin & Nonpartisan & $\$ 10,000 / \$ 1,000^{d}$ & Midwest & 10 & 7 \\
\hline Michigan & Semi-partisan & $\$ 3,400$ & Midwest & 8 & 7 \\
\hline Ohio & Semi-partisan & $\$ 6,000 / \$ 6,900^{\mathrm{e}}$ & Midwest & 6 & 7 \\
\hline Illinois & Partisan/Retention & No Limits & Midwest & 10 & 7 \\
\hline New Mexico & Partisan/Retention & No Limits & Southwest & 8 & 5 \\
\hline Pennsylvania & Partisan/Retention & No Limits & Northeast & 10 & 7 \\
\hline West Virginia & Partisan & $\$ 1,000$ & Southeast & 12 & 5 \\
\hline Louisiana & Partisan & $\$ 5,000$ & Southeast & 10 & 7 \\
\hline Alabama & Partisan & No Limits & Southeast & 6 & 9 \\
\hline
\end{tabular}

Source: National Institute on Money in State Politics. http://www.followthemoney.org.

${ }^{a}$ Contribution limits on individuals per candidate per election cycle at the supreme court level prior to the 2010 election.

b Prior to 2009, there were no contribution limits in Minnesota. A 2009 amendment to the Minnesota Code of Judicial Conduct changed the limit to $\$ 2,000$ in an election year and $\$ 500$ in a non-election year.

c There were no contribution limits in Washington prior to 2006. Legislation in 2006 limited contributions to $\$ 1,600$ in the primary and $\$ 1,600$ in the general election.

d Prior to 2009, contribution limits were set at $\$ 10,000$. The 2009 Impartial Justice Bill reduced the limit to $\$ 1,000$.

e Prior to 2009 , contributions were limited to $\$ 3,000$ in the primary and $\$ 3,000$ in the general election. After 2009, the limits were increased to $\$ 3,450$ in the primary and $\$ 3,450$ in the general election.

The data for campaign contributions were obtained from the National Institute on Money in State Politics. The Institute receives its data from the state disclosure agencies with which candidates file their campaign finance reports. They collect the data for all state-level candidates in primary and general elections and put it into a data set. The data are then organized by state 
and election year. I identified the attorneys of record in each case and then matched them to the campaign finance reports for the candidates after sorting the donors alphabetically.

\section{Dependent Variable}

The dependent variable is coded 1 if the judge voted for the appellant and 0 if the judge voted for the respondent. An appellant vote is one in which the judge votes to reverse the lower court's decision, while a vote for the respondent affirms the lower court's decision.

\section{Independent Variables}

The main independent variable is the campaign contribution differential between the lawyers representing the appellants and the lawyers representing the respondents in each case. It is necessary to use the differential since judges sometimes receive contributions from both sides. I only included contributions made to judges in the election immediately preceding a decision, and only from lawyers and law firms listed as attorneys of record in the case. A simple crosstabs analysis, presented in Figure 1, demonstrates the connection between campaign contributions and votes for the appellant in this sample. ${ }^{6}$ The first two columns on each side of the graph represent a zero or negative differential (i.e. the respondent's side contributed the same or more than the appellant's side). The third column on each side represents a positive contribution differential, that is, the appellant's side contributed more than the respondent's. When the contribution differential is zero or negative, judges voted with appellants less than 50 percent of the time (46.9 percent and 43.6 percent respectively). However, when there is a positive contribution differential, the percentage jumps to 67.2 percent $-\mathrm{a} 23.6$ percent increase in votes for the appellant when shifting from a negative to a positive differential.

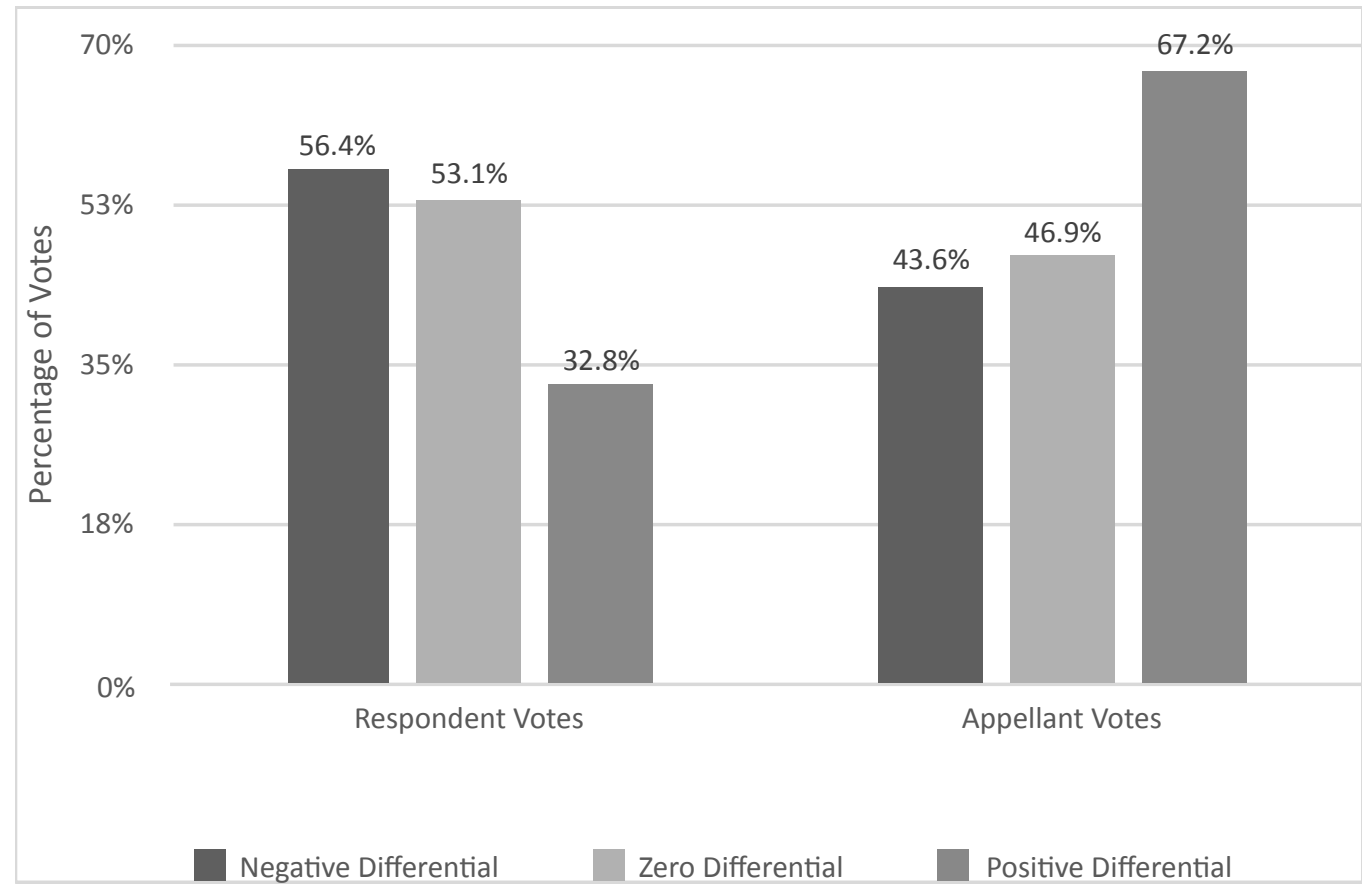

Figure 1. Percentage of Votes for Appellant by Contribution Differential

The second independent variable is the percent of the vote the judge received in the previous election. ${ }^{7}$ This variable represents the competitiveness of a judicial seat, and therefore, the amount of electoral pressure the judge faces. In order to compare judges with low and high 
vote percentages I created a dummy variable based on the median of 63 percent for the entire sample. ${ }^{8}$ Judges who received less than 63 percent of the vote were coded 0 and judges who received 63 percent or more were coded 1 . I also created a dummy variable for ballot type. The states are coded 0 for nonpartisan and 1 for partisan.

\section{Interaction Terms}

The purpose of the interaction terms is to test whether the relationship between campaign contributions and votes for the appellant is conditional on the two other variables of interest (Vote Percentage and Ballot Type). The expectation is that the interaction effect will be negative for both.

\section{Control Variables}

In order to control for other explanatory factors, I included nine control variables in the models. ${ }^{9}$ The first control variable is for discretionary appeals since mandatory dockets give rise to more frivolous appeals in which the appellate court is likely to affirm the lower court's ruling (Hettinger, Lindquist, and Martinek 2006). Furthermore, judges exercising discretionary jurisdiction are more likely to select cases reflecting their ideological preferences (Brace, Yates, and Boyea 2012). The second is a dummy variable for civil and criminal cases to control for case type. Third, I control for majority and dissenting votes to ensure the results are not simply a reflection of judges voting with the majority in every case. The fourth is the type of representation the appellant received. Law firms bring more resources to bear on a case, and may be more selective about the types of clients they represent on appeal. Therefore, appellants represented by law firms should have a higher rate of success. The fifth control variable represents the total number of amicus participants supporting the appellant in each case. Greater support from amicus curiae is likely to improve the appellant's chances of winning (Songer and Kuersten 1995). The final four variables control for whether the state or a business was an appellant or respondent in the case, since the state has a higher winning percentage on appeal than other litigants in this sample, and pro-business judges are likely biased towards business litigants. Tables $1 \mathrm{~A}$ and $2 \mathrm{~A}$ in the Appendix provide descriptions and summary statistics for each variable.

\section{Estimation Method}

I utilize a multi-level model to account for within cluster associations for judges and states. Since the dependent variable is dichotomous, I use maximum likelihood estimation. The regression models are presented in Tables 2 and 5. The use of interaction terms in nonlinear models is tricky because the interaction effect is conditional on the independent variables and may have different signs for different values of covariates (Norton, Wang, and Ai 2004). Consequently, "the test for the statistical significance of the interaction effect must be based on the estimated cross-partial derivative, not on the coefficient of the interaction term" (Norton, Wang, and Ai 2004, 156). Thus, after running the regression models, I calculated and graphed the cross-partial derivatives and marginal effects for each interaction term. 


\section{Results}

The logistic regression results for the first model are presented in Table 2. Interpreting logit coefficients is difficult, especially with the inclusion of an interaction term, but the findings in Table 2 are consistent with other methods of analysis discussed in this section. The first coefficient (.00013) represents the rate of change in the log-odds of y given a one dollar increase in Contribution Differential. Nevertheless, the inclusion of the interaction term means the standard errors for the lower-order variables (Contribution Differential and Vote Percentage) are conditioned on the other variables. Therefore, the coefficient for Contribution Differential represents the effect of increased contributions from the appellant's side when Vote Percentage is equal to zero (i.e. low vote percentage). The coefficient for Contribution Differential is positive and statistically significant at the $<.05$ level, indicating that contributions have a positive effect on appellant votes within the sample of judges who received a low percentage of the vote in the previous election. This evidences a link between judges who ran in closely contested races and their donors. However, the interaction term is negative and not statistically significant, which means the relationship between contributions and votes does not hold up for judges who received a high percentage of the vote. That is to say, when switching from a low to a high vote percentage, the contribution differential is no longer a significant predictor of votes for the appellant. 
Table 2. Likelihood of a Vote for the Appellant (Multi-level logit model)

\begin{tabular}{|c|c|}
\hline Independent Variables & Coefficient \\
\hline Contribution Differential & $\begin{array}{l}.00013^{*} \\
(.00005)\end{array}$ \\
\hline Vote Percentage & $\begin{array}{l}-.04169 \\
(.10330)\end{array}$ \\
\hline Differential x Vote Percentage & $\begin{array}{l}-.00008 \\
(.00007)\end{array}$ \\
\hline Discretionary Appeal & $\begin{array}{l}.84478^{* * *} \\
(.16216)\end{array}$ \\
\hline Civil Case & $\begin{array}{c}-.32196^{\dagger} \\
(.16400)\end{array}$ \\
\hline Majority Vote & $\begin{array}{l}-.00162 \\
(.15355)\end{array}$ \\
\hline Law Firm & $\begin{array}{l}.45378^{* * *} \\
(.10881)\end{array}$ \\
\hline Amicus Support & $\begin{array}{l}.18601^{* *} \\
(.05580)\end{array}$ \\
\hline Respondent-State & $\begin{array}{l}-1.15182 * * * \\
(.18633)\end{array}$ \\
\hline Respondent-Business & $\begin{array}{l}-.52848 * * * \\
(.12025)\end{array}$ \\
\hline Appellant-State & $\begin{array}{l}.34106^{*} \\
(.14750)\end{array}$ \\
\hline Appellant-Business & $\begin{array}{l}.00783 \\
(.12873)\end{array}$ \\
\hline Intercept & $\begin{array}{l}-.47888 \\
(.30148)\end{array}$ \\
\hline Observations & 2600 \\
\hline Log likelihood & -1594.8582 \\
\hline Wald $\chi^{2}$ & $218.14 * * *$ \\
\hline
\end{tabular}

$* * * \mathrm{p}<.001, * * \mathrm{p}<.01, * \mathrm{p}<.05, \dagger \mathrm{p}<.10$ (two tailed) 
While contributions are the focus of this study, there are several other significant predictors of appellant votes worth noting. The difference between discretionary and mandatory appeals is highly significant. Judges exercising discretion over the cases they heard were more likely to vote to reverse the lower court's decision. Moreover, the types of support appellants' received impacted their rate of success. Appellants represented by law firms were more successful than those represented by solo practitioners, and support from amici curiae increased the odds of a favorable decision, as well. Finally, the cases in which appellants had the least amount of success were those where the state or a business was the respondent.

\section{Interaction Effects}

The preliminary results from the logit regression are instructive, but interpreting the logit coefficient from the regression model is not a reliable way of determining the direction and significance of an interaction term in a nonlinear model. However, by calculating the crosspartial derivatives, it is easy to determine where the data points lie. We can expect most observations to be clustered around the mean cross-partial derivative, which in this case is -.0000138 (See Table 3). The marginal effect for judges who received a high percentage of the vote is .0000151 , while the marginal effect for judges who received a low percentage is . 0000289, resulting in a mean interaction effect of -.0000138 . This means the conditional probability of a vote for the appellant based on a one dollar change in the contribution differential decreases by .0000138 when switching between a low and high vote percentage. The important point is that the marginal effect of Contribution Differential on the dependent variable is higher in the sample of judges who received a low percentage of the vote. In other words, judges who ran in close elections were more likely to vote with contributors than judges who won by a large percentage of the vote. This suggests that the relationship between contributions and votes is not consistent throughout, but is contingent on the competitiveness of the previous election. 
Table 3. Mean Interaction Effects

\begin{tabular}{cccc}
\hline Interaction Terms & cross-partial derivative & standard error & Z-statistic \\
\hline Differential x Vote Percentage & -.0000138 & .0000167 & -.8270673 \\
Low Percentage & .0000289 & & \\
High Percentage & .0000151 & & \\
Differential x Ballot Type & -.0000361 & .0000258 & -1.391738 \\
Nonpartisan Ballot & .0000534 & & \\
Partisan Ballot & .0000173 & & \\
\hline
\end{tabular}

For ease of interpretation, Figure 2 plots the predicted probabilities of a vote for the appellant based on the interaction effect. Unlike the marginal effects which are the partial difference in $y$ given a one-unit change in $x$, the predicted probabilities are simply the probability that $y=1$ at different values of $x$. Figure 2 shows that the probabilities of a vote for the appellant increase as the contribution differential increases in both the low percentage and high percentage samples. However, when moving from a negative differential of $-\$ 10,000$ to a positive differential of $\$ 10,000$, the probability of a vote for the appellant increases from .26 to .82 for judges who received a low percentage of the vote (an increase of .56), while the probability increases from .42 to .67 for judges who received a high percentage (an increase of only .25). Thus, there is a noticeable difference in the magnitude of the effect between the two samples. In fact, at every point on the right side of the graph where there is a positive differential, the probabilities are higher for judges who received a low percentage of the vote. 


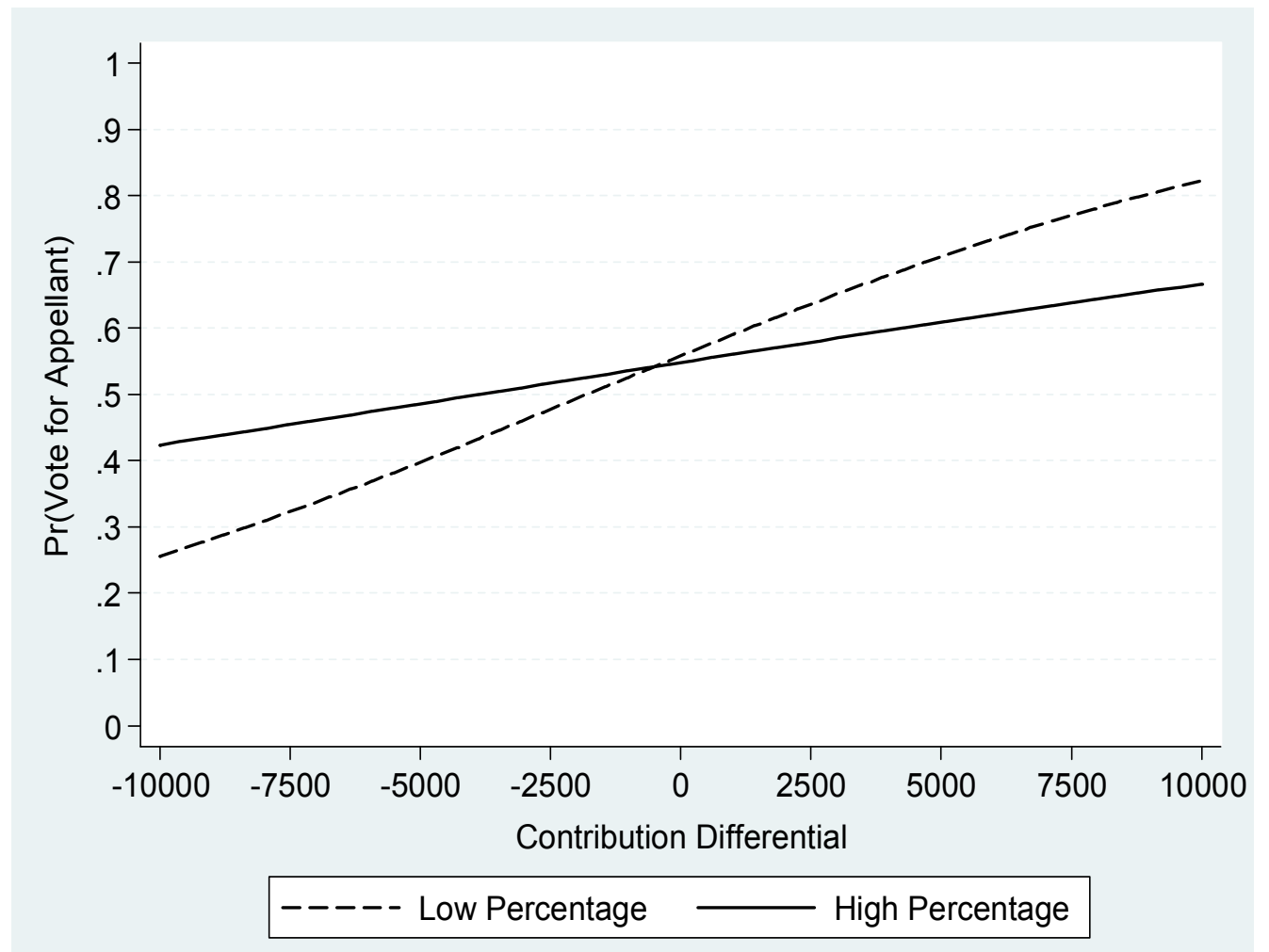

Figure 2. Probability of a Vote for the Appellant by Vote Percentage

As already noted, looking at the logit coefficient from the regression model is not a reliable way of determining the direction and significance of an interaction term because the sign may vary for different observations (Norton, Wang, and Ai 2004). However, by graphing the cross-partial derivatives for the interaction term in Figure 3, it is clear that most of them are negative and clustered near the mean (-.0000138). 


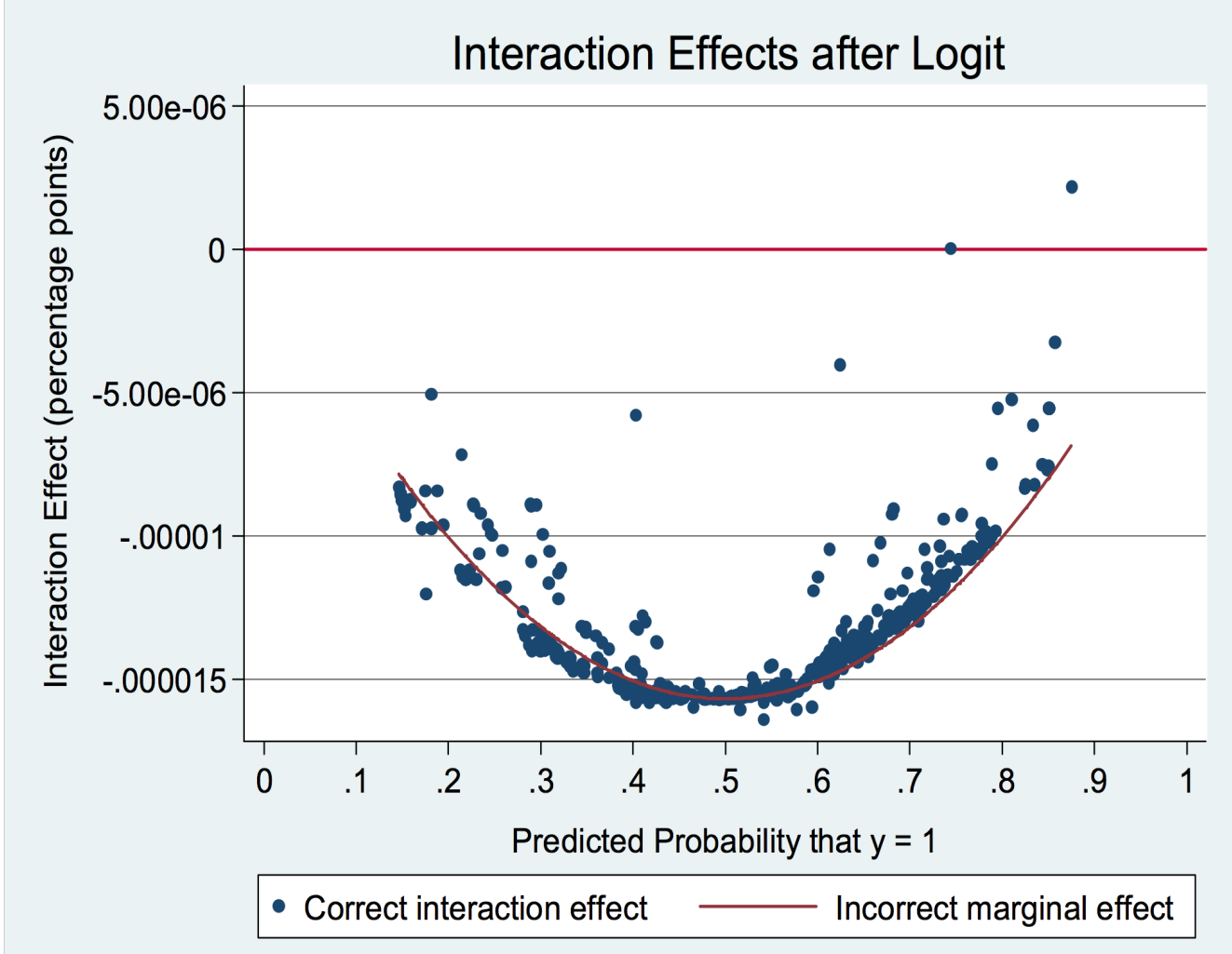

Figure 3. Interaction Effects for Contribution Differential and Vote Percentage

It is also possible to compute the derivative with respect to one variable at different values of the other variable (Karaca-Mandic, Norton, and Dowd 2012). In order to do this, I took the difference in the marginal effects between the high and low vote percentage samples at various contribution differential levels and plotted them in Figure 4. As the left side of the graph shows, when the contribution differential is negative, the difference in the marginal effects between the two samples is positive (i.e. the marginal effect is greater in the high percentage sample). This is consistent with the predicted probabilities in Figure 2. However, as the contribution differential increases on the right side of the graph, the difference in the marginal effects between the two samples is negative. This shift is indicative of a decrease in the marginal effects for the high percentage sample compared to the low percentage sample as the contribution differential increases. 


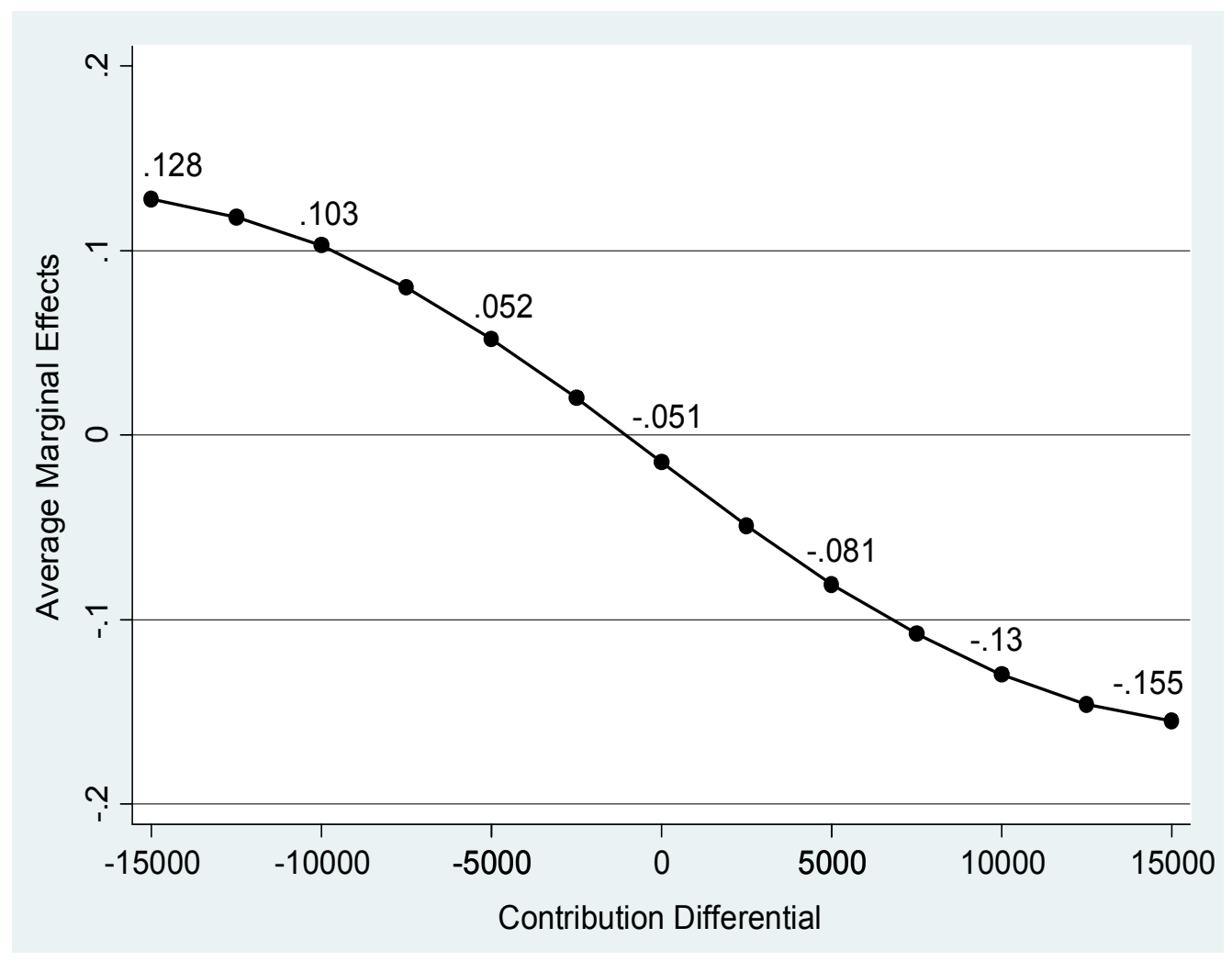

Figure 4. Difference in the Marginal Effects between High and Low Vote Percentage at Various Contribution Differential Levels

As the final part of the analysis, I separated the observations by case type and ran bivariate regressions between contribution differential and votes for the appellant to see if the relationship is consistent throughout the sample. The results reveal some important insights (See Table 4). While all the coefficients are positive, only three are statistically significant at the $<.10$ level-property, contracts and insurance - the case types most likely to involve business interests. The coefficient for criminal cases is borderline, but not quite significant. Noticeably, the case types most likely to involve individual litigants - torts and family — are not significant. This makes sense theoretically, since cases involving personal injury or divorce are not likely to garner a lot of outside interest. Overall, there is strong evidence to support the first hypothesis, but the relationship may only exist in a specific subset of case types. 
Table 4. Bivariate Regressions by Case Type

\begin{tabular}{llll}
\hline Case Type & Coefficient & p-value & $\mathrm{N}$ \\
\hline Property & $.00028^{*}$ & .024 & 241 \\
Contracts & $.00235^{*}$ & .032 & 122 \\
Insurance & $.00139^{\dagger}$ & .083 & 89 \\
Criminal & .00054 & .140 & 1145 \\
Torts & .00015 & .251 & 264 \\
Family & .00077 & .727 & 146 \\
Labor & .00001 & .971 & 127 \\
Other & .00002 & .762 & 643 \\
\hline
\end{tabular}

$* * * \mathrm{p}<.001, * * \mathrm{p}<.01, * \mathrm{p}<.05, \dagger \mathrm{p}<.10$ (two tailed)

Next, I tested the second hypothesis to see if there is a difference between judges in the nonpartisan and partisan samples. This involves looking at the interaction effect between Contribution Differential and Ballot Type. I expect judges in the nonpartisan sample to vote more often with contributors, when controlling for other factors, since they are less beholden to political parties and freer to reward individual contributors. The results for the second model are displayed in Table 5. Similar to the first model, the inclusion of the interaction term means the standard errors for the lower-order variables (Contribution Differential and Ballot Type) are conditioned on the other variables. Therefore, the coefficient for Contribution Differential represents the effect of increased contributions from the appellant's side when Ballot Type is equal to zero (i.e. nonpartisan). The coefficient is positive and statistically significant at the <.05 level, indicating that contributions have a positive effect on votes in the nonpartisan sample. Conversely, the interaction term is negative and not statistically significant, meaning the relationship between contributions and votes is not significant for judges in the partisan sample. Thus, when switching from nonpartisan to partisan states, the contribution differential is no longer a significant predictor of votes for the appellant. 
Table 5. Likelihood of a Vote for the Appellant (Multi-level logit model)

\begin{tabular}{|c|c|}
\hline Independent Variables & Coefficients \\
\hline Contribution Differential & $\begin{array}{l}.00046^{*} \\
(.00021)\end{array}$ \\
\hline Ballot Type & $\begin{array}{l}.41157 \\
(.25617)\end{array}$ \\
\hline Differential x Ballot Type & $\begin{array}{l}-.00015 \\
(.00012)\end{array}$ \\
\hline Discretionary Appeal & $\begin{array}{l}.85842 * * * \\
(.15641)\end{array}$ \\
\hline Civil Case & $\begin{array}{r}-.32717 * \\
(.15948)\end{array}$ \\
\hline Majority Vote & $\begin{array}{l}.02068 \\
(.14974)\end{array}$ \\
\hline Law Firm & $\begin{array}{l}.46006 * * * \\
(.10595)\end{array}$ \\
\hline Amicus Support & $\begin{array}{l}.20406 * * * \\
(.05479)\end{array}$ \\
\hline Respondent-State & $\begin{array}{l}-1.10090 * * * \\
(.18170)\end{array}$ \\
\hline Respondent-Business & $\begin{array}{l}-.55636 * * * \\
(.35250)\end{array}$ \\
\hline Appellant-State & $\begin{array}{l}.35250 * \\
(.14328)\end{array}$ \\
\hline Appellant-Business & $\begin{array}{l}.09046 \\
(.12436)\end{array}$ \\
\hline Intercept & $\begin{array}{l}-.75162 * \\
(.32974)\end{array}$ \\
\hline Observations & 2774 \\
\hline Log likelihood & -1696.9853 \\
\hline Wald $\chi^{2}$ & $233.73 * * *$ \\
\hline
\end{tabular}


Consistent with the second hypothesis, the mean interaction effect from Table 3 is also negative $($ mean $=-.0000361$ ). However, after graphing the predicted probabilities for the interation term in Figure 5, it is apparent that contributions increase the probability of a vote for the appellant in both the partisan and nonpartisan samples - the difference is in the magnitude. In the nonpartisan sample, the probabilities increase from .11 to .89 as the contribution differential increases (an increase of .78), while in the partisan sample the probabilities increase from .43 to .75 (an increase of only .32).

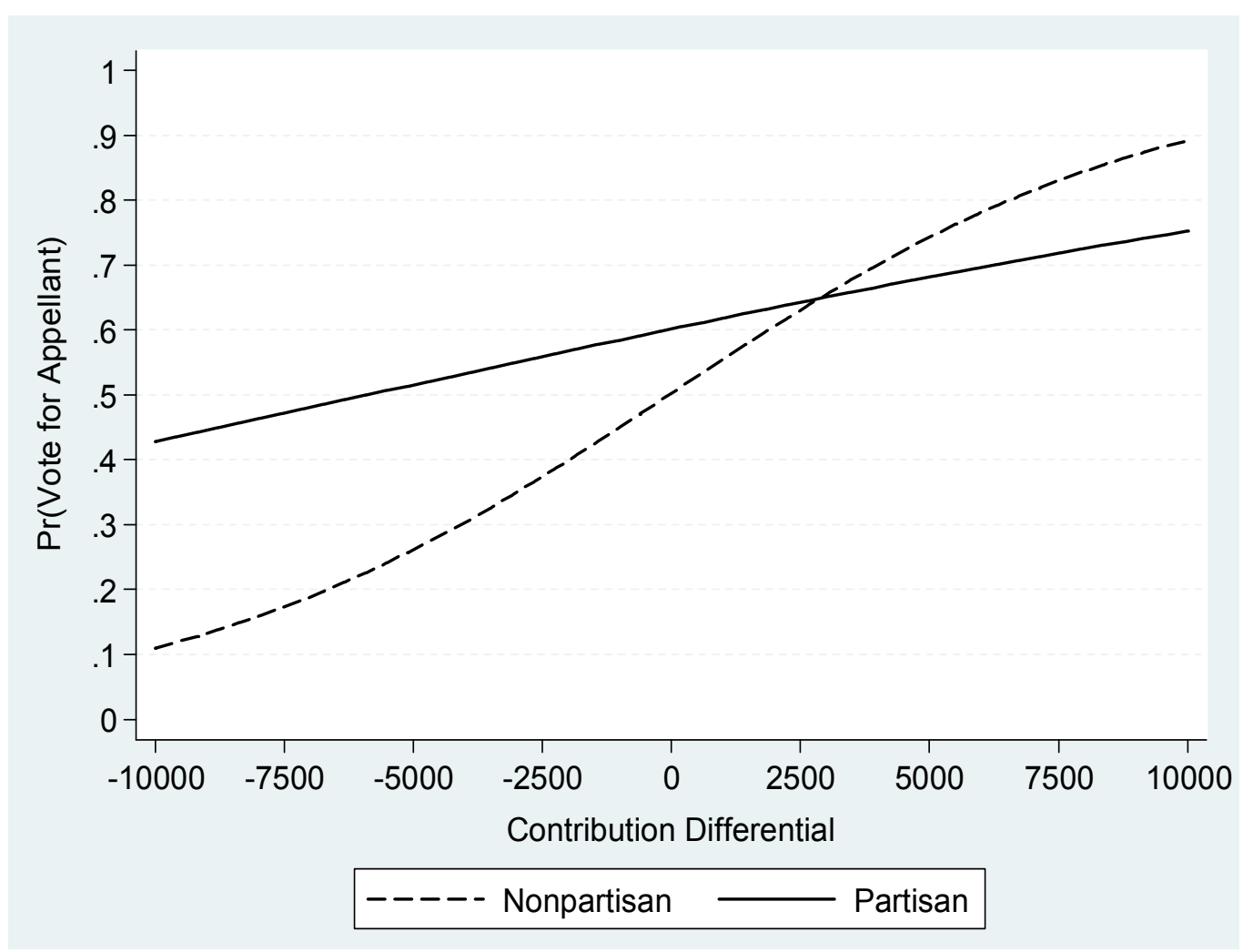

Figure 5. Probability of a Vote for the Appellant by Ballot Type

Notably, judges in the partisan sample are more likely to vote with the appellant when the contribution differential is zero or negative, but an increase in contributions from the appellant's side causes a major shift in support for the appellant in the nonpartisan sample. In fact, support for the appellant is quite low among nonpartisan judges when there is a negative differential, but an increase in contributions changes the picture entirely. The conclusion that can be drawn from the probabilities in Figure 5 is that contributions have a greater impact in the nonpartisan sample. 
As I did for the first hypothesis, I plotted the cross-partial derivatives for the second interaction term between Contribution Differential and Ballot Type in Figure 6. The interaction effects for most of the observations are negative, although the magnitudes vary, and most of the observations are clustered around the mean (-.0000361).

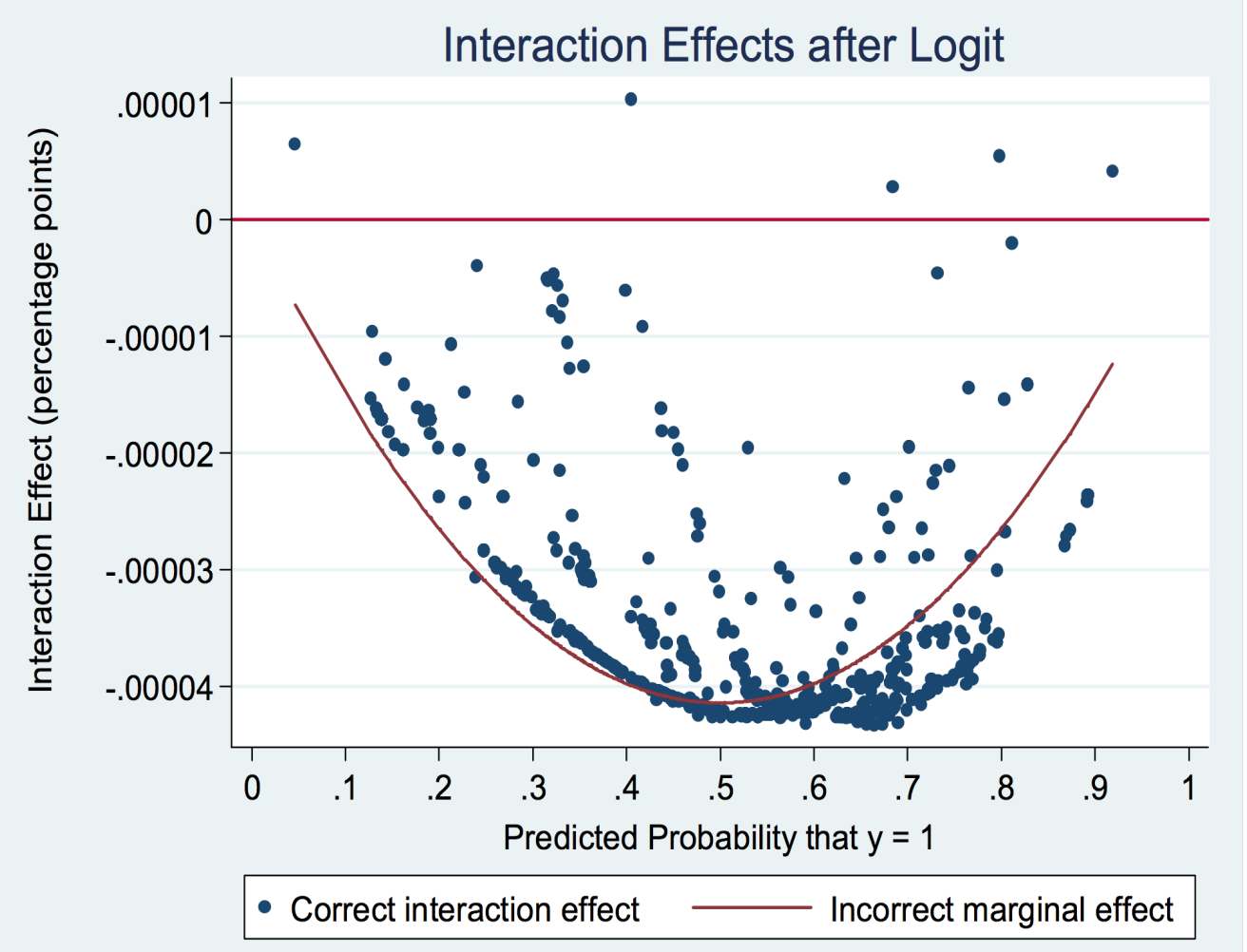

Figure 6. Interaction Effects for Contribution Differential and Ballot Type 
The final step in the statistical analysis for the second hypothesis was plotting the differences in the marginal effects for the second interaction term. These are presented in Figure 7. As the graph shows, the differences in the marginal effects between partisan and nonpartisan ballots decrease as the contribution differential increases. The marginal effects in the partisan sample are higher when the contribution differential is zero or negative (differences are positive). This is consistent with the predicted probabilities in Figure 5. However, this changes as the marginal effects in the nonpartisan sample increase and surpass those in the partisan sample as the contribution differential increases (differences are negative). This is further evidence that switching from partisan to nonpartisan ballots increases the impact of contributions on appellant votes.

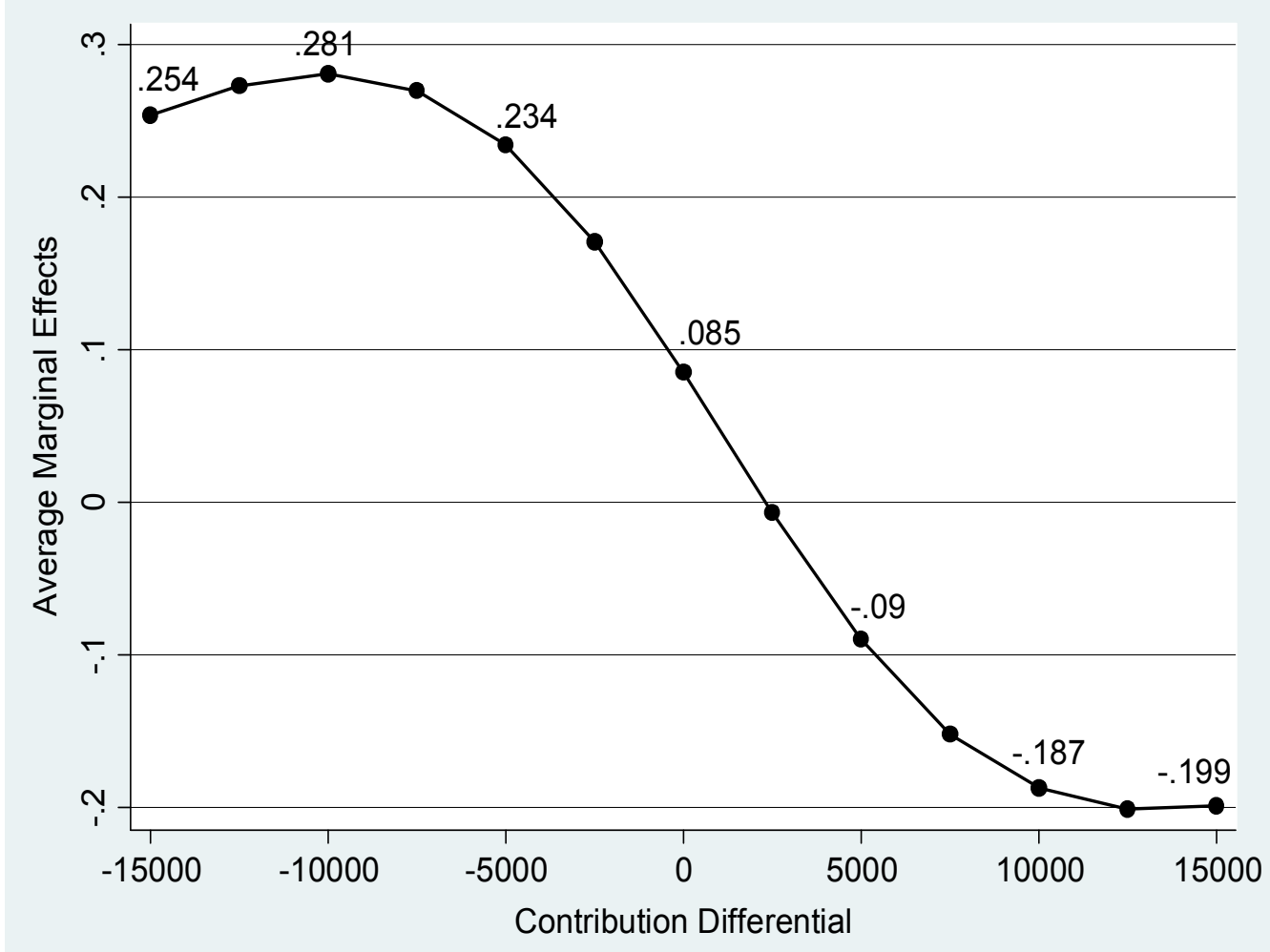

Figure 7. Difference in the Marginal Effects between Partisan and Nonpartisan Ballots at Various Contribution Differential Levels

It is important to note that there is a sizable difference in the amount of contributions from lawyers in the nonpartisan and partisan samples. There were $\$ 146,411$ total contributions in the nonpartisan sample compared to $\$ 611,361$ in the partisan sample. Hence, the amount of contributions in the partisan sample is much greater, but the impact of the contributions on votes appears to be less significant. 


\section{Discussion and Conclusion}

This study is an important contribution to the ongoing debate over judicial selection methods. It lends support to the argument that judges who win tightly contested races may be susceptible to influence from contributors who appear before them in court. ${ }^{10}$ This evidences a link between contributions and votes which is contingent on election results and the competitiveness of that particular seat.

These findings are part of a growing body of research showing that judges are not immune from the corrupting influence of money in politics. As campaign dollars flow into judicial elections from wealthy donors, parties, special interests, and even litigants who appear before the bench, judges will lose a certain degree of impartiality. Judicial elections may increase accountability and voter turnout, but at the expense of judicial independence from outside influences. This reflects the trade-off between elective and appointive systems.

Nevertheless, there does not appear to be widespread support to move to merit-based systems. Despite the fact that an overwhelming majority of the public believes elected judges are influenced by campaign contributions (Geyh 2003), we are actually seeing a decline in support for merit-based systems (Bonneau 2012). In at least seven states there have been efforts to weaken or eliminate merit selection of judges in recent years (Skaggs, et al. 2011). In these states, voters want to retain the power to remove judges, even if it means sacrificing a certain amount of impartiality to do so. There may also be recognition by many voters that merit selection systems are as political as contested elections. The only difference may be that judges selected in a merit-based system are more likely to reflect the ideological preferences of the bar, rather than their constituents (Fitzpatrick 2009).

As an alternative to adopting merit-selection systems, some states have moved to nonpartisan ballots as a sort of compromise between impartiality and accountability. This solution has its own problems, though. On the whole, nonpartisan elections see lower voter participation, fewer contested elections for incumbents, and a higher margin of victory for incumbents when they are contested (Bonneau and Hall 2009). ${ }^{11}$ Furthermore, as the results from this study indicate, nonpartisan elections may actually decrease impartiality by increasing the link between donors and judges.

While this study adds to the existing research on the connection between campaign contributions and judicial votes, more research and innovative statistical methods are needed on this topic. Future research should also be extended to the trial court level where relationships between lawyers and judges are more personal. Contributions are likely to have an even greater impact at the trial court level where lawyers and local judges interact personally and professionally on a daily basis.

I would like to thank Mark McKenzie, Tim Nokken and Cindy Rugeley for their comments on an early version of this project. This research was supported (in part) by a summer stipend from the Research Center for the Humanities and Social Sciences at William Paterson University. 


\section{Appendix}

Table 1A. Variable Descriptions

Variable

Variable Description

Dependent Variable

Votes for Appellant

1 is a vote for the appellant, 0 is a vote for the respondent

Independent Variables

Contribution Differential

Total campaign contributions by the lawyers for the appellant minus the total campaign contributions by the lawyers for the respondent

Vote Percentage

Percentage of the vote the judge received in the previous election $(0<63 \%=0,63 \leq 100 \%=1)$

Ballot Type

0 if nonpartisan ballot, 1 if partisan ballot

Type of Appeal

Discretionary Appeal

0 if matter of right, 1 if discretionary

Case Type

Civil Case

0 if criminal case, 1 if civil case

Decision

Majority Vote

0 if dissenting vote, 1 if majority vote

Type of Representation

Law Firm

1 if the appellant was represented by a law firm, 0 otherwise

Interest Group Involvement

Amicus Curiae Support

Total number of amici supporting the appellant

Litigant Type

Respondent-State

1 if the respondent was the state, 0 otherwise

Respondent-Business

1 if the respondent was a business, 0 otherwise

Appellant-State

1 if the appellant was the state, 0 otherwise

Appellant-Business

1 if the appellant was a business, 0 otherwise 
Table 2A. Summary Statistics

\begin{tabular}{lccccc}
\hline Independent Variables & Min & Max & Mean & Median & S.D. \\
\hline Contribution Differential & $-15,300$ & $17,710.39$ & -35.13 & 0 & $1,158.15$ \\
Vote Percentage & 0 & 1 & .50 & 1 & .50 \\
Ballot Type & 0 & 1 & .48 & 0 & .50 \\
Discretionary Appeal & 0 & 1 & .65 & 1 & .48 \\
Civil Case & 0 & 1 & .59 & 1 & .49 \\
Majority Vote & 0 & 1 & .91 & 1 & .28 \\
Law Firm & 0 & 1 & .40 & 0 & .49 \\
Amicus Support & 0 & 12 & .28 & 0 & .89 \\
Respondent-State & 0 & 1 & .30 & 0 & .46 \\
Respondent-Business & 0 & 1 & .20 & 0 & .40 \\
Appellant-State & 0 & 1 & .23 & 0 & .42 \\
Appellant-Business & 0 & 1 & .20 & 0 & .40 \\
& & & & & \\
\hline
\end{tabular}




\section{Notes}

${ }^{1}$ Campaign costs also vary by state and media market. In some markets, a campaign dollar goes farther than in others.

${ }^{2}$ Shepherd's (2009) sample of retired judges was small, which may explain the lack of significance using a probit model.

${ }^{3}$ In order to address the issue of endogeneity, Cann (2007) substituted instrumental variables for campaign contributions and then utilized a two-stage probit least squares estimator. The instruments he used were whether the judge was contested in the previous election and the presence of a public defender or district attorney. I tried a similar method, but was unable to find an appropriate instrument for these models.

${ }^{4}$ I included Michigan and Ohio in the partisan sample since they hold partisan primaries, and the campaign contributions data cover the entire election cycle.

${ }^{5}$ Information about each state's selection method and campaign finance regulations were obtained from the American Judicature Society. http://www.judicialselection.us/judicial_selection/

${ }^{6}$ Over the whole sample, donors appeared before their judge in 16.5 percent of the votes.

${ }^{7}$ I use vote percentage instead of margin of victory, but the use of either variable yields similar results. In the case of plurality wins, I feel vote percentage is a more accurate reflection of the competitiveness of that seat.

${ }^{8}$ I use the median percentage as an unbiased demarcation point to separate judges in this sample. It does not represent an equilibrium point or have any other generally applicable significance.

${ }^{9}$ Previous models included several judge-specific control variables for political party, whether the judge was elected or appointed to fill a vacancy, and whether the judge was a freshman or senior judge. However, the judge-specific variables had a negligible effect on the models and did not improve their explanatory power.

${ }^{10}$ The U.S. Supreme Court's decision in Caperton v. Massey $(2009,14)$ requires elected judges to recuse themselves “...when a person with a personal stake in a particular case had a significant and disproportionate influence in placing the judge on the case by raising funds or directing the judge's election campaign when the case was pending or imminent." However, the Court's opinion also states that not every campaign contribution by a litigant or attorney requires recusal. Caperton was an exceptional case due to the $\$ 3$ million spent by a business litigant on a judge's campaign prior to a pending case.

${ }^{11}$ In nonpartisan states, incumbent supreme court judges are only defeated in their reelection bids 5.2 percent of the time compared to 31.4 percent in partisan elections (Bonneau and Hall 2009). 


\section{References}

Andersen, Seth. 2004. "Examining the Decline in Support for Merit Selection in the States." Albany Law Review 67 (Spring): 793-802.

Arbour, Brian K., and Mark J. McKenzie. 2010. "Has the 'New Style' of Judicial Campaigning Reached Lower Court Elections?” Judicature 93 (January-February): 150-160.

Bond, Jon R., Cary Covington, and Richard Fleisher. 1985. "Explaining Challenger Quality in Congressional Elections.” The Journal of Politics 47(2): 510-529.

Bonneau, Chris W. 2005. "What Price Justice(s)? Understanding Campaign Spending in State Supreme Court Elections.” State Politics and Policy Quarterly 5 (Spring): 107-125.

Bonneau, Chris W. 2012. "A Survey of Empirical Evidence Concerning Judicial Elections.” Federalist Society White Paper (March).

Bonneau, Chris W., and Damon Cann. 2011. "Campaign Spending, Diminishing Marginal Returns, and Campaign Finance Restrictions in State Supreme Court Elections." Journal of Politics 73 (4): 1-14.

Bonneau, Chris W. and Melinda G. Hall. 2009. In Defense of Judicial Elections. New York: Routledge.

Brace, Paul, and Brent D. Boyea. 2008. "State Public Opinion, the Death Penalty, and the Practice of Electing Judges.” American Journal of Political Science 52 (April): 360-372.

Brace, Paul R. and Melinda G. Hall. 1997. "The Interplay of Preferences, Case Facts, Context, and Rules in the Politics of Judicial Choice." Journal of Politics 59 (November): 12061231.

Brace, Paul R., Jeff Yates, and Brent D. Boyea. 2012. "Judges, Litigants, and the Design of Courts.” Law \& Society Review 46(3): 497-522.

Caldarone, Richard P., Brandice Canes-Wrone, and Tom S. Clark. 2009. "Partisan Labels and Democratic Accountability: An Analysis of State Supreme Court Abortion Decisions." Journal of Politics 71 (April): 560-573.

Cann, Damon M. 2002. "Campaign Contributions and Judicial Behavior.” American Review of Politics 23 (Fall): 261-274.

Cann, Damon. 2007. "Justice for Sale? Campaign Contributions and Judicial Decisionmaking." State Politics and Policy Quarterly 7 (Fall): 281-297.

Cann, Damon M., Chris W. Bonneau, and Brent D. Boyea. 2012. "Campaign Contributions and Judicial Decisions in Partisan and Nonpartisan Elections." In New Directions in Judicial Politics, edited by Kevin T. McGuire. New York: Routledge.

Cann, Damon M. and Teena Wilhelm. 2011. "Case Visibility and the Electoral Connection in State Supreme Courts.” American Politics Research 39 (May): 557-581. 
Caperton v. A.T. Massey Coal Co. 2009. 556 U.S. 868.

Fitzpatrick, Brian T. 2009. "The Politics of Merit Selection.” Vanderbilt Law Review 74 (Summer): 675-709.

Frederick, Brian and Matthew J. Streb. 2011. "The Cost of Going for the Gavel: Individual Candidate Spending in Intermediate Appellate Court Elections.” Justice System Journal 32 (1): $25-43$.

Geyh, Charles G. 2003. "Why Judicial Elections Stink.” Ohio State Law Journal 64 (1): 43-79.

Geyh, Charles G. 2016. Courting Peril: The Political Transformation of the American Judiciary. New York: Oxford University Press.

Gordon, Sanford C. and Gregory A. Huber. 2007. "The Effect of Electoral Competitiveness on Incumbent Behavior.” Quarterly Journal of Political Science 2 (May): 107-138.

Hall, Melinda G. 1987. "Constituency Influence in State Supreme Courts: Conceptual Notes and a Case Study." Journal of Politics 49: 1117-1124.

Hall, Melinda G. 1992. "Electoral Politics and Strategic Voting in State Supreme Courts." Journal of Politics 54 (May): 427-446.

Hall, Melinda G. 1995. "Justices as Representatives: Elections and Judicial Politics in the American States.” American Politics Quarterly 23 (October): 485-503.

Hall, Melinda G., and Chris W. Bonneau. 2006. "Does Quality Matter? Challengers in State Supreme Court Elections.” American Journal of Political Science 50: 20-33.

Hettinger, Virginia A., Stefanie A. Lindquist, and Wendy L. Martinek. 2006. Judging on a Collegial Court: Influences on Federal Appellate Decision Making. Charlottesville, VA: University of Virginia Press.

Hogan, Robert E. 2004. "Challenger Emergence, Incumbent Success, and Electoral Accountability in State Legislative Elections." The Journal of Politics 66(4): 1283-1303.

Kang, Michael S., and Joanna M. Shepherd. 2011. "The Partisan Price of Justice: An Empirical Analysis of Campaign Contributions and Judicial Decisions.” New York University Law Review 86(April 2011): 69-130.

Kang, Michael S., and Joanna M. Shepherd. 2013. "The Partisan Foundations of Judicial Campaign Finance.” Southern California Law Review 86: 1239-1308.

Karaca-Mandic, Pinar, Edward C. Norton, and Bryan Dowd. 2012. "Interaction Terms in Nonlinear Models.” HSR: Health Services Research 47(1): 255-274. 
Langer, Laura. 2002. Judicial Review in State Supreme Courts: A Comparative Study. Albany: SUNY Press.

McCall, Madhavi. 2003. "The Politics of Judicial Elections: The Influence of Campaign Contributions on the Voting Patterns of Texas Supreme Court Justices, 1994-1997.” Politics \& Policy 31 (June): 314-343.

Norton, Edward D., Hua Wang, and Chunrong Ai. 2004. "Computing Interaction Effects and Standard Errors in Logit and Probit Models.” The Stata Journal 4(2): 154-167.

Peters, C. Scott. 2007. "Canons, Cost, and Competition in State Supreme Court Elections." Judicature 91:27-35.

Pritchard, Anita. 1992. "Strategic Considerations in the Decision to Challenge a State Legislative Incumbent.” Legislative Studies Quarterly 17(3): 381-393.

Rock, Emily, and Lawrence Baum. 2010. "The Impact of High-Visibility Contests for U.S. State Court Judgeships: Partisan Voting in Nonpartisan Elections." State Politics and Policy Quarterly 10 (Winter): 368-396.

Shepherd, Joanna M. 2009. “Money, Politics, and Impartial Justice.” Duke Law Journal 58 (January): 623-685.

Skaggs, Adam, Maria da Silva, Linda Casey, and Charles Hall. 2011. The New Politics of Judicial Elections 2009-10. Washington, DC: Justice at Stake Campaign.

Songer, Donald R., and Ashlyn Kuersten. 1995. "The Success of Amici in State Supreme Courts.” Political Research Quarterly 48(1): 31-42.

Van Dunk, Emily. 1997. “Challenger Quality in State Legislative Elections.” Political Research Quarterly 50(4): 793-807.

Waltenburg, Eric N., and Charles S. Lopeman. 2000. "Tort Decisions and Campaign Dollars." Southeastern Political Review 28: 241-263.

Ware, Stephen J. 1999. "Money, Politics, and Judicial Decisions: A Case Study of Arbitration Law in Alabama." Journal of Law and Politics 25: 645-686.

Wright, Gerald C., and Brian F. Schaffner. 2002. "The Influence of Party: Evidence from the State Legislatures.” American Political Science Review 96(2): 367-379. 